\title{
COGNITIVE MODELING AND MULTI CRITERIA DECISION MAKING IN MACROECONOMIC ANALYSIS
}

\begin{abstract}
Decision making in macroeconomics belongs to the class of ill-structured tasks with strong external factors interdependence, a limited number of management tools and experts groups' subjectivity. This paper suggests a technique of macroeconomic analysis which includes methods of cognitive modeling for formalizing a problem situation and scenario generation as a basis of the typical multicriteria decision making task. In turn, for solving this task is suggested a method based on measuring the distance to the «ideal» solution with determining importance of criteria by finding objective, common component of all values measured by experts groups. For extracting this «commonality» means of factor analysis are used. Such an approach allows separating of the objective part in experts' value from a subjective one, while the technique at whole provides formalization of macroeconomic problems and substantiation of decisionmaking in macroeconomics.

Key words: cognitive modeling, combined strategies, decision making, ill-structured problems, macroeconomic analysis, method of finding generality, multicriteriality
\end{abstract}

\section{Introduction}

Decision making is a critical problem for any branch of knowledge involving decision situations. However decision making theory (DM) as an applied mathematical tool for foundation of any possible choice is quite rare used yet. For most of typical economic tasks both factors influenced on their formulation and means of their solutions have high level of uncertainty. Even in cases where nominal scales are possible and estimation is conducted by expert groups these tasks are poorly satisfied with most DM methods requirements. And while in microeconomics there are particular types of task which can be adopted for DM means, macroeconomists mostly base their choice on theoretical analysis of connections and interactions.

Nina Leonova, PhD Candidate, Higher School of Economics, National Research University, Moscow, Russia, e-mail: nina.leonova@gmail.com 
A typical formulation of initial conditions is "while A is increasing, B is reducing". These types of connection in a fact make the foundation of macroeconomic analysis. Some of them are quite clear, while other vary much with every scientist's opinion. In dependency on which economic school he or she belongs to, what makes sphere of interests and etc. Consequently, decision making process has an obligate subjective part. From the one hand it is possible to solve the problem by using expert groups consisted of scientists from different economic schools, holding different opinions on the situation discussed. In that case we will get estimations based on sufficient amount of subjective opinions. Expectedly they will be objective enough. From the other hand it causes a number of other problems such as extracting of aforementioned objective part from the whole set of obtained estimations and determining factors used as criteria. Macroeconomics assumes existence of different points of

view for the same problem, it is impossible to detect the best one, thereby an "ideal" solution as well as factors influence on its' achievement varies from each economist, each expert. Consequently, in the situation of determining criteria under the consequences of different vies existence there are two ways to adopt it: either to cut all criteria which are in doubt for at least one of the experts or to take into account any criteria suggested by any expert. The result of the first solution is the cropped model allows an effective application of mathematical tools. Such a model however is not satisfied with economic theory point of view. While the second way results in a large dimensions evaluation matrix of alternatives (strategies) that leads to the problem of DM methods application.

Furthermore there is an explicit problem of initial set of alternatives determination. In the ideal case it is necessary to detect all possible ways of the problem's solution. Such a situation limits experts' opportunities. Instruments of fiscal and monetary politics are quite fixed in macroeconomic theory, while their characteristics are again described by statements "while A is increasing, B is reducing". So there are conditions of accurate numerical characteristics absence. It is quite obvious that for economic theory is more typical manipulating by causality, not quantity factors. Certainly, there are assumptions as "while A is increasing by $3 \%, \mathrm{~B}$ is $1 \%$ falling". However, such statements represent conclusions based on empirical observations (statistical data). Thereby DM tasks in macroeconomics unlike the task of for example choice of a family car, which is well-structured and easy formalized, require special methods providing transition from causality and verbal estimates to accurate mathematical language.

One more complication of classic DM methods application to developing effective macroeconomic strategies is influence of external factors or factors of variable external environment. This fact in substance is the essence of macroeconomic theory. Moreover dynamic nature of the tasks also results in some additional problems. Importance of criteria changes over time in case of economic long and short run as well as in general sense - every month, every day, every 
minute. Thus, an individual decision-maker (IDM) is in the situation of choice due to the lack of complete information about external environment conditions and quantitative dynamics of criteria what results in the absence of determinate connection between strategies and its consequences, which could be recorded as functional dependency.

Furthermore people who are IDMs in macroeconomic also form a standalone question. Two main features of specialists working in this sphere are quite obvious. First, their number is limited enough: legislative and administration affairs specialists, board of directors of national monetary authority and the president. Any others, analytics and consultants, can be considered only as experts, but they can't be a part of IDM group. It leads to the second feature - the high degree of IDM responsibility. Thus, every macroeconomic decision should be the reasoned one, separated from the subjective part. Besides it, for some cases their reasonableness must be explained for people who don't have special knowledge in the sphere, such an explanation should be clear and available for everybody. Exactly this necessity of formal foundation together with requirements of objectiveness form factors called for strict mathematical tools as supporting means of making critical macroeconomic decisions.

So, there is a number of main problems which limit opportunities of classical DM methods. They in turn results in requirements for a new suitable for such situations method:

1) Ill-structuring of macroeconomic theory. Using of natural language for its description.

2) A limited leverage leading to limited number of alternative scenario.

3) Subjective nature of theoretical part.

4) Let's consider each of them analyzing opportunities for their solution.

\section{Ill-structuring tasks}

Methods suitable for ill-structured problems which require modeling of external and internal environment are based on using expert information processed with the help of heuristics, common sense and intuition. This fact, however, does not detract from this approach objectivity, but only helps with accurate and literate formalization of the situation. Among these methods the most popular are cognitive maps, decision tree and the analytic hierarchy process. The main advantage of cognitive modelling for macroeconomic tasks is presentation of expert knowledge in the form of the scheme where are recorded casual effects of factors characterizing the situation. Furthermore this method is suitable for generating management solutions in the form of strategies (Avdeeva and Kovriga, 2010). In fact, the set of factors and casual network connecting them form a fuzzy cognitive map (FCM). FCM in this situation is representa- 
tion of IDM's view on the system, its' features, principles and consistent patterns. Besides, FCMs meet the dynamic nature of the task, recording connections between future, present and past of the considerable process (Plotinskij, 1998). The core of FCM is signed directed graph, vertexes of which are criteria and alternatives, while arcs are causalities. In addition it is necessary to select manageable factors or concepts (which in fact are alternatives) and target factors (criteria). Beside it, graph could contain quite big amount of vertexes representing factors which are neither target, not manageable (or limited manageable). Their presence however is obligatory for accurate description of the system's rules. Such factors are called intermediate. External environment influence in such models is represented by external concepts. Their values are just observed and depend on external factors which are out of the model. DM tasks under such consequences require determination of alternatives' initial values which are necessary for achievement specified values of target factors. Examples of cognitive maps are available in (Evstegneev and Ledasheva, 2003; and Kulinich, 2001).

\section{Alimited number of alternatives}

Using of FCMs is however possible only for the specified set of initial alternatives. Under this method all the manageable concepts (graph's vertexes) pulses simultaneously, they represented as a vector contained initial values of factors important for the system dynamics. Thereby an alternative is not only any pure strategy but the combination of them. In such a statement pure strategy is just a part or a component of the mixed or combined one. Component is one of the part in which conditionally divided a pure (100\%) alternative. Components could be some measurable parameters as well as separated structured parts of the alternative.

Thus, in macroeconomic application we speak about the combination of actions, tools which all together form the united strategy aimed at achievement the specified states of economy. Such an approach to a great extend is differ from classic methods of DM by reason of using combined strategies instead of the choice the only one what is common practice. For a linear task considering influence on manageable concepts, these concepts are directly connected with criteria through estimations. When internal and external impulses are taken into account those connections accrete by intermediate internal and external factors and can be even broken by them. It leads to a nonlinear task where the "ideal" strategy is almost always the combined one. Dealing with such tasks requires first of all the set of any possible combination from $n$ alternatives generation. The resulting combinations should meet the following conditions: each of them should differ from any other by at least one part of the alternative; the set at the whole should contain all single, double and ternary and other $m$ combinations of alternatives, where $\mathrm{m}$ is a maximum number of alternatives' combinations. 
Using of combined strategies is very important for estimating possibility of the method application to macroeconomic tasks, when it is quite obvious that through influence on the only one factor it is impossible to get quality changes in the whole system. The situation is analogical e.g. for decision making in politics.

\section{Subjective nature of theoretical part}

As discussed above one of the major problems in economic modelling is the variability of views on the situation and presence of significant subjective part in each of them. From the one hand it leads to criteria overgrowth that transforms the task in multicriteria one. From the other hand it entails a problem of assigning weights for them by an experts group. Classical methods of DM require numerical weights assigned by experts. This is complication enough for specialist used to deal with verbal categories. It can be solved by e.g. transition from quantity characteristics to categories like "A criteria is more important than B criteria". However, in this case we get a problem of agreed opinions. In this work is supported to use a method of commonality which doesn't require experts for assigning weights. It is described in detail in (Perminov and Leonova, 2012, pp. 1267-1276).

The essence of the method is using means of factor analysis for finding new common factors, which replace the initial ones, with the further determining the path of each combination of alternatives taking into account an objective part embedded in the set of the estimations made by an experts group. The next step is to find the best (minimal or maximal in dependency of aims) estimation using resulting path. On the base of such estimations are constructed a matrix of alternatives' paths deviations from the ideal one. The best alternative is the one gotten the shortest distance from the "ideal". Under conditions of combined strategies instead of pure, essence of the method is the same, but the size of the matrix will increase by reason of the growing number of all potential solutions due to taking into account all possible combinations of alternatives. In addition, the fact of taking into consideration external and internal environments factors transfers the system into nonlinear one. It results in requirement of using dynamic (asymptotic) estimations instead of classic static ones. The fact is quite important not only by the reason of economic system dynamic nature, but also taking into account that interaction of inverses connections could quite down the system as well as shake it. 


\section{Practical implementation}

For the demonstration of the method let's consider its' application to the generalized problem of capital outflow regulation in Russia. The subject nowadays is very popular and actual. It is complicated and questionable enough in its economic essence, that's why for this paper we limit the problem by elementary and obvious factors which characterize the indicator. It is quite enough for illustration how the method deals with typical problems of macroeconomic tasks.

Thus, we have a task of the capital outflow regulation (reduction). Let's list all the steps of the method:

1) Determination and analysis of factors and casual effects typical for the situation. FCM constructing.

2) FCM calculation with the aim at generation of combined strategies and the matrix construction.

3) Using the method of finding commonality for getting the best combined alternative.

Let's consider each step on the application to the specified task.

We take monetary policy tools (refinancing rate, reserve requirements), fiscal policy tools (aggregate indicator of tax policy rigidity) and indicator of privatization's actions as manageable concepts. So as a base concept for generation mixed strategies are considered instruments available for monetary authority and government. Open market operations are excluded by the reason of statistical data absence for the recent five years. For the same reasons there are no transfers and government expenditures in the list ${ }^{1}$. Inclusion of privatization's indicator concept in the consideration is due to its' importance exactly for russian economy, what is quite obvious by turning to the recent economic history of the country.

Such economic indicators as foreign direct inward and outward investment (as a main part of capital outflow), current account, GDP, CPI, economic stability and corruption level (as important ones for investment climate factors) are represented as target concepts - criteria in DM definitions. Banking sector liquidity indicator, money supply, external debt, total government debt, trade balance, dollar USA/ruble exchange rate, tax revenues, export, an aggregated indicator of metal prices, oil and gas prices, political stability and offshore policy form intermediate external and internal concepts ${ }^{2}$. Each of specified factors is represented

The practical calculation in the paper intends to demonstrate the supporting method and doesn't pretend to be full and accuracy from economical point of view. From the other hand using of long enough time series guarantees identification of the rules in the indicator's dynamics. Thus, such an assumption for this paper could be quite adequate.

2 Most of time series are constructed on the base of statistical data compiled and published by Bank of Russia, Federal state statistics service in the Russian Federation, IMF and OECD. 
by weighted digraph's vertex. Casual effects form its' arcs, each of them gets its' own weight illustrated the strength of the effect. For constructing such an presentation adjacency matrices are convenient enough. An adjacency matrix is a table with rows and columns corresponding to the nodes of the digraph while elements on their intersections reflects the presence of the arc, its' direction and strength. The adjacency matrix of the considered task is illustrated on Fig. $1^{3}$.

FCM has been constructed on the base of the adjacency matrix. There is a great number of the special software for it. For this research is used decision support system based on cognitive modeling "IGLA" with options of FCMs modeling, generation and selection of scenario for management ill-strutted systems constructed on the base FCMs (Gulakov, Lagerev and Podvesovski, 2007, pp. 103-104).

Figure 1: The adjacency matrix.

\begin{tabular}{|c|c|c|c|c|c|c|c|c|c|c|c|c|c|c|c|c|c|c|c|c|c|c|c|c|c|}
\hline & 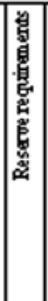 & 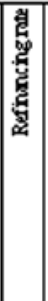 & 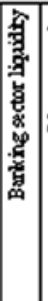 & 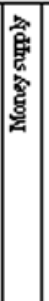 & 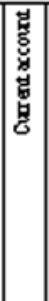 & 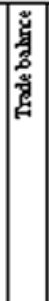 & 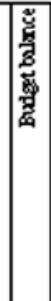 & 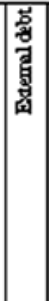 & 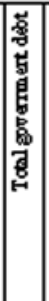 & 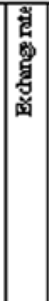 & 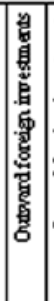 & 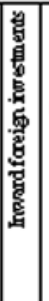 & 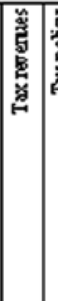 & . & 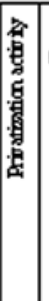 & 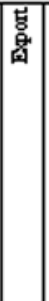 & 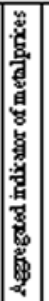 & 总 & 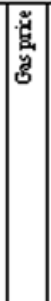 & 官 & $\overline{\mathrm{B}}$ & 畕 & 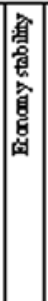 & 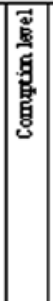 & 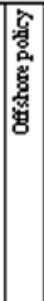 \\
\hline Reserve requirements & - & $\cdot$ & $-0,4$. & .09 & $\cdot$ & $\cdot$ & $\cdot$ & $\cdot$ & & 0,2 & $-0,4$ & $\cdot$ & $\cdot$ & $\cdot$ & $\cdot$ & $\cdot$ & - & $\cdot$ & $\cdot$ & 0,03 & -0.9 & & & $\cdot$ & \\
\hline Refimmingrate & . & $\cdot$ & .09. & .09 & - & . & - & $\cdot$ & 0.2 & 0.2 & -0.4 & & $\cdot$ & . & . & $\cdot$ & . & $\cdot$ & $\cdot$ & .03 & -0.8 & & & . & \\
\hline Bamkingsector liquility & - & $\cdot$ & $\cdot$ & 09 & $\cdot$ & 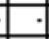 & $\cdot$ & $\cdot$ & & -0.3 & -03 & & $\cdot$ & $\cdot$ & $\cdot$ & $\cdot$ & - & $\cdot$ & $\cdot$ & .02 & 0.8 & & & $\cdot$ & \\
\hline Maney supply & - & $\cdot$ & $\cdot$ & - & $\cdot$ & . & - & $\cdot$ & & $-0,2$ & $\cdot$ & & - & . & - & $\cdot$ & . & - & $\cdot$ & & 0.8 & & & - & . \\
\hline Currert acoount & . & $\cdot$ & . & - &. & . & 0,0 & . & . & - & $\cdot$ & 02 & $-0,1$ & . & - &. & . & - & . & & - & 7 & . & . & . \\
\hline Trade balance & - & $\cdot$ & $\cdot$ & & 0.8 & $\cdot$ & 0.4 & . & $\cdot$ & 0.6 & $\cdot$ & & $-0,1$ & $\cdot$ & + & $\cdot$ & $\cdot$ & $\cdot$ & $\cdot$ & & $\cdot$ & & & $\cdot$ & $\cdot$ \\
\hline Budgt belance & . & - & . & - & - & . & & $-0,3$ & - & - &. & & 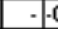 & .03 . & .08 &. & . & - &. & &. & $-0,4$ & 0,1 & - & . \\
\hline Butamaldebt & - & - & $\cdot$ & - & $\cdot$ & & $-0,0$ & 0.4 & - & - & $\cdot$. & $-0,6$ & $\cdot$ & $\cdot$ & + & - & . & - & . & & - & & & - & \\
\hline Totol govamet debt & - & $\cdot$ & $\cdot$ & & $\cdot$ & & -0.8 & $\cdot$ & $\cdot$ & - & $\cdot$ & & $\cdot$ & $\cdot$ & $\cdot$ & - & - & - & $\cdot$ & & -5 & & - & $\cdot$ & - \\
\hline Exhange rate & $\cdot$ & $\cdot$ & $\cdot$ & & $-0,6$ & $-0,6$ & & $-a, 4$ & $\cdot$ & $\cdot$ & 0.2 . & .02 & $0,3 \mathrm{C}$ & 0.2 & & -0.9 & & $\cdot$ & $\cdot$ & $-0,4$ & $-0,4$ & -02 & & - & • \\
\hline Outward foreiginotmerts & - & $\cdot$ & .03. & .02 & $-0,2$ & $-0,4$ & -02 & $\cdot$ & & -0.5 & $\cdot$ & 02. & $-0,45$ & 0,1 & + & $\cdot$ & $\cdot$ & $\cdot$ & $\cdot$ & 02 & $-0,1$ & -03 & 03 & $\cdot$ & 02 \\
\hline mwardforeign invesments & 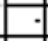 & $\cdot$ & 03 & 02 & 0,2 & 0.4 & 0,4 & $\cdot$ & & 0,7 & 02 & & 0.4 & $\cdot$ & + & 0,5 & 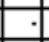 & $\cdot$ & $\cdot$ & 02 & 0.1 & 02 & 03 & $\cdot$ & $\cdot$ \\
\hline Toxrevenues & - & $\cdot$ & $\cdot$ & $\cdot$ & $\cdot$ & & 09 & 0.3 & 02 & $\cdot$ & $\mid-0,1$ & & $\cdot$ & $\cdot$ & 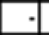 & $\cdot$ & $\cdot$ & $\cdot$ & $\cdot$ & 0,1 & $\cdot$ & & & - & $\cdot$ \\
\hline Twxoliy & - & $\cdot$ & $\cdot$ & & 0.2 & 03 & \begin{tabular}{|c|c|}
3 \\
\end{tabular} & $\cdot$ & $\cdot$ & $\cdot$ & 0.6 . & .0 .6 & 0.1 & $\cdot$ & - & $\cdot$ & + & $\cdot$ & $\cdot$ & & -5 & -0.1 & & $\cdot$ & $\cdot$ \\
\hline Privimtian actioiy & - & $\cdot$ & $\cdot$ & & $\cdot$ & & 02 & $\cdot$ & & $\cdot$ & $\cdot$ & 02 & $\cdot$ & . & - & $\cdot$ & & $\cdot$ & . & & $\cdot$ & -0.2 & 0.3 & 0,2 & $\cdot$ \\
\hline Bpat & - & - & $\cdot$ & & 0,9 & 09 & 0,4 & $\cdot$ & & 0,1 & $\cdot$ & & - & . & - & $\cdot$ & 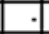 & $\cdot$ & $\cdot$ & 02 & $\cdot$ & & & $\cdot$ & . \\
\hline Azgegted indixata of metalprioes & - & $\cdot$ & $-0,1$. & .02 & $\cdot$ & 0,1 & & $\cdot$ & 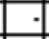 & $\cdot$ & $\cdot$ & $\cdot$ & \begin{tabular}{|c|}
$\cdot$ \\
\end{tabular} & . & $\cdot$ & $\cdot$ & $\cdot$ & - & $\cdot$ & 0,1 & $\cdot$ & & 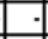 & $\cdot$ & $\cdot$ \\
\hline Oilprixe & - & - & $\cdot$ & & 0,8 & 09 & 03 & -0.2 & 02 & 0.8 & $\cdot$ & 0,1 & 0.2 & . & - & 0,9 & & - & $\cdot$ & 03 & - & 03 & 0.5 & - & - \\
\hline Gasprice & - & - & $\cdot$ & & 0.6 & 0.7 & 02 & -0.1 & 0,1 & 0,2 & $\cdot \cdot$ & 0,1 & 0,1 & $\cdot$ & & 0.7 & & - & $\cdot$ & 0,1 & - & 02 & 02 & - & - \\
\hline GDP & $\cdot$ & $\cdot$ & \begin{tabular}{|c|}
$\cdot$ \\
\end{tabular} & & $\cdot$ & . & 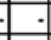 & $\cdot$ & 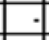 & $\cdot$ & $\cdot$ & . & $\cdot$ & . & .02 & $\cdot$ & . & $\cdot$ & $\cdot$ & . & $\cdot$ & 02 & 02 & $\cdot$ & . \\
\hline CPI & 0.1 & 0,1 & 0,1 & 02 & $\cdot$ & & & $\cdot$ & & $\cdot$ & $\cdot$ & & $\cdot$ & $\cdot$ & - & $\cdot$ & & $\cdot$ & $\cdot$ & & -1 & $-0,1$ & .02 & $\cdot$ & - \\
\hline Poltíalstability & & $a, 1$ & $\cdot$ & & - & $\cdot$ & - & . & & - & $\cdot$ & 0,4 & - & . & - & $\cdot$ & - & - & . & - & - & & & $-0,2$ & \\
\hline Ecanamy stability & 0,1 & 0,2 & $\cdot$ & + & $\cdot$ & 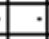 & & $-a, 1$ & 0,1 & - & $\cdot$ & 0,4 & $\cdot$ & $\cdot$ & + & $\cdot$ & + & $\cdot$ & $\cdot$ & & $\cdot$ & & 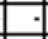 & $\cdot$ & $\cdot$ \\
\hline Comution kvel & - & $\cdot$ & . & $\cdot$ & $\cdot$ & . & $\cdot$ & $\cdot$ & $\cdot$ & $\cdot$ & 02 & & -0.2 & . & $\cdot$ & $\cdot$ & & $\cdot$ & . & &. & -0.5 & 0.4 & $\cdot$ & \\
\hline Offshare poliy & . & $\cdot$ & $\cdot$ & $\cdot$ & $\cdot$ & 7 & - & $\cdot$ & $\cdot$ & $\cdot$ & $-0,4$ & -02 & 0.2 & & & $\cdot$ & & $\cdot$ & $\cdot$ & & $\cdot$ & 0.1 & & $-a, 1$ & \\
\hline
\end{tabular}

For that class of the tasks an adjacency matrix, as well as internal and external factors of the problem are formed and signed by the experts who are specialist of this branch of knowledge. 
For application this method in "IGLA" software it is required to specify initial values of concepts using a special fuzzy rank scale. It consists of seven levels: very low, low, below average, average, above average, high, very high. It is quite obvious that such estimations are made by experts on the base of their view on the situation in question. Thus, analyzed task is represented by four manageable concepts; each of them could get seven different values according to the ranks scale ${ }^{4}$. The software generates $4^{7}$ mixed strategies, for each of them manageable factors get one of seven different values according to the ranks scale. The result of the process is presented as a matrix contained values of the concepts for each alternative. Further, we should exclude values of non-target concepts, which are not criteria in DM definitions. The latest version of the matrix is presented on Fig. 2.

$4 \quad$ The scale differs a little from the one used for determining initial values of factors and consists of four ranks: very low, below average, above average, very high. 
Cognitive modeling and multi criteria decision making...

163

Figure 2: A fragment of the matrix under conditions of mixed strategies

\begin{tabular}{|c|c|c|c|c|c|c|c|}
\hline $\begin{array}{l}\text { Alternative } \\
\text { nomber }\end{array}$ & $\begin{array}{l}\text { Current } \\
\text { account }\end{array}$ & $\begin{array}{c}\text { Outward } \\
\text { foreign } \\
\text { investments }\end{array}$ & $\begin{array}{c}\text { Inward } \\
\text { foreign } \\
\text { investments }\end{array}$ & GDP & CPI & $\begin{array}{l}\text { Economy } \\
\text { stability }\end{array}$ & $\begin{array}{c}\text { Corruption } \\
\text { level }\end{array}$ \\
\hline 170 & 0,80 & 0,81 & 0,62 & 0,63 & 0,26 & 0,47 & 0,42 \\
\hline 171 & 0,80 & 0,81 & 0,63 & 0,63 & 0,26 & 0,45 & 0,45 \\
\hline 172 & 0,81 & 0,84 & 0,58 & 0,63 & 0,25 & 0,51 & 0,34 \\
\hline 173 & 0,81 & 0,84 & 0,58 & 0,63 & 0,25 & 0,48 & 0,38 \\
\hline 174 & 0,81 & 0,84 & 0,59 & 0,63 & 0,25 & 0,46 & 0,42 \\
\hline 175 & 0,81 & 0,84 & 0,60 & 0,63 & 0,25 & 0,44 & 0,45 \\
\hline 176 & 0,76 & 0,71 & 0,67 & 0,62 & 0,15 & 0,52 & $\overline{0,34}$ \\
\hline 177 & 0,76 & 0,72 & 0,68 & 0,62 & 0,16 & 0,50 & 0,38 \\
\hline 178 & 0,76 & 0,72 & 0,68 & 0,62 & 0,16 & 0,48 & 0,42 \\
\hline 179 & 0,76 & 0,72 & 0,68 & 0,62 & 0,16 & 0,48 & 0,42 \\
\hline 180 & 0,78 & 0,75 & 0,64 & 0,62 & 0,15 & 0,52 & $\overline{0,34}$ \\
\hline 181 & 0,78 & 0,75 & 0,65 & 0,62 & 0,15 & 0,50 & 0,38 \\
\hline 182 & 0,78 & 0,75 & 0,65 & 0,62 & 0,15 & 0,48 & 0,42 \\
\hline 183 & 0,78 & 0,76 & 0,66 & 0,62 & 0,16 & 0,46 & 0,45 \\
\hline 184 & 0,79 & 0,79 & 0,61 & 0,61 & 0,15 & 0,52 & 0,34 \\
\hline 185 & 0,79 & 0,79 & 0,61 & 0,61 & 0,15 & 0,49 & 0,38 \\
\hline 186 & 0,79 & 0,79 & 0,62 & 0,62 & 0,15 & 0,47 & 0,42 \\
\hline 187 & 0,79 & 0,79 & 0,63 & 0,62 & 0,15 & 0,45 & 0,46 \\
\hline 188 & 0,80 & 0,82 & 0,58 & 0,61 & 0,14 & 0,51 & 0,34 \\
\hline 189 & 0,80 & 0,82 & 0,58 & 0,61 & 0,15 & 0,49 & 0,38 \\
\hline 190 & 0,80 & 0,83 & 0,59 & 0,61 & 0,15 & 0,47 & 0,42 \\
\hline 191 & 0,81 & 0,83 & 0,60 & 0,61 & 0,15 & 0,45 & 0,46 \\
\hline 192 & 0,77 & 0,74 & 0,67 & 0,64 & 0,37 & 0,52 & 0,34 \\
\hline 193 & 0,77 & 0,75 & 0,68 & 0,64 & 0,37 & 0,49 & 0,38 \\
\hline 194 & 0,77 & 0,75 & 0,69 & 0,64 & 0,37 & 0,47 & 0,41 \\
\hline 195 & 0,78 & 0,75 & 0,69 & 0,64 & 0,38 & 0,45 & 0,45 \\
\hline 196 & 0,79 & 0,78 & 0,64 & 0,64 & 0,36 & 0,51 & 0,34 \\
\hline 197 & 0,79 & 0,78 & 0,65 & 0,64 & 0,37 & 0,49 & 0,38 \\
\hline 198 & 0,79 & 0,78 & 0,66 & 0,64 & 0,37 & 0,47 & 0,41 \\
\hline 199 & 0,79 & 0,79 & 0,66 & 0,64 & 0,37 & 0,45 & 0,45 \\
\hline 200 & 0,80 & 0,82 & 0,61 & 0,64 & 0,36 & 0,51 & 0,34 \\
\hline 201 & 0,80 & 0,82 & 0,62 & 0,64 & 0,36 & 0,48 & 0,38 \\
\hline 202 & 0,80 & 0,82 & 0,62 & 0,64 & 0,37 & 0,46 & 0,41 \\
\hline 203 & 0,80 & 0,82 & 0,63 & 0,64 & 0,37 & 0,44 & 0,45 \\
\hline 204 & 0,81 & 0,85 & 0,58 & 0,64 & 0,36 & 0,50 & 0,34 \\
\hline 205 & 0,82 & 0,85 & 0,59 & 0,64 & 0,36 & 0,48 & 0,38 \\
\hline 206 & 0,82 & 0,86 & 0,59 & 0,64 & 0,36 & 0,46 & 0,42 \\
\hline 207 & 0,82 & 0,86 & 0,60 & 0,64 & 0,37 & 0,44 & 0,45 \\
\hline
\end{tabular}

Vol. 11, No 3, 2014: 155-166 
To get an effective alternative we will use the finding commonality method. With the help of factor analysis we calculate principle components, which replace criteria. In application to our data we get three principle components, which has $100 \%$ percentage of variance. For extraction commonality from individuals scores it is necessary to multiply commonality regression coefficients at value of alternatives estimations. The next step is determining criteria goal: whether it requires to be minimized or maximized for achievement an effective results, after that we find the "ideal" path for them and with the help of Euclidean distance ${ }^{5}$ calculate the distance to it. Further, selecting out the shortest distance value we get the most effective alternative. Such an alternative in application to used data implies very low reserve requirement and refinancing rate, high tax policy rigidity and deceleration activity of privatization process.

\section{Conclusion}

This result doesn't satisfy all requirements to be suitable for accurate economic interpretation by the reason of excluded macroeconomic tools. However, it is quite obvious that it doesn't conflict with basic economic rules. Thus, we can say that this technique is suitable for the class of ill-structured tasks with great influence and strong variability of external environment, experts groups' subjectivity, priority of combined strategies over pure ones and a great number of criteria which an optimal solution should meet. The fact, in turn, shows possibility of the method application in wide sphere of macroeconomic tasks.

\section{Literature}

- $\quad$ Avdeeva Z. K., Kovriga S.V. (2010) Heuristic method for conceptual structurization of knowledge in the course of ill-structured situations formalization based on cognitive. Upravlenije Bol'shimi Sistemami (pp.6-34). Russia, Moscow: Institute of Control Sciences, Russian Academy of Sciences.

- Gulakov V.K., Lagerev D.G., Podvesovskij A.G (2007) Decision support system based on cognitive modeling "IGLA". Programmnye produkty i sistemy (pp. 103-104). Russia, Moscow.

- Evstegneev D.V., Ledasheva T.N (2003), Cognitive maps in complex evaluation of territory condition, Researched in Russia, Russia, Moscow: Moscow Institute of Physics and Technology. Retrieved 03.07.2013 from http://zhurnal.ape.relarn.ru/articles/2003/135.pdf

In (Perminov G.I., Leonova N.V., 2012) is demonstrated dependency between a chosen metric space and a final result. 
- Kulinich A.A. (2001) Subject-oriented system of conceptional modeling "Kanva". Materials of the First International conference "Cognitive analysis and situation development management". Russia, Moscow.

- Plotinskij J.M. (1998) Social process model, Russia, Moscow: Logos.

- Perminov G.I., Leonova N.V. (2012) The Method of Determining Importance of Criteria in a Multicriteria Decision Problem. China-USA Business Review, (pp. 1267-1276) USA, EL Monte: David Publishing Company. 


\title{
Mr Nina Leonova
}

Viša ekonomska škola,

Nacionalni istraživački univerzitet, Moskva, Rusija

\section{KOGNITIVNO MODELIRANJE I MULTIKRITERIJALNE ODLUKE U ANALIZI MAKRO EKONOMIJE}

\begin{abstract}
S a ž e t a k
Proces donošenja odluka u makroekonomiji pripada klasi loše zamišljenih zadataka sa snažnim spoljnim faktorima međuzavisnosti, ograničenim brojem menadžmenta i subjektivnim ekspertnim grupama. Rad pokazuje tehniku makroekonomske analize koja uključuje metode kognitivnog modeliranja pri formalizovanju određenih problematičnih situacija i generacijskog scenarija kao osnovu tipičnog multikriterialnog donošenja odluka. S ciljem rešavanja ovog zadatka, predložen je metod osnovan na merenju dostižnosti „idealanog“ rešenja utvrđivanjem vrednosti kriterijuma za pronalaženjem cilja i zajedničkih komponenata svih vrednosti, od strane odabranih stručnjaka. Za utvrđivanje „oskudne povezanosti forme“ korištene su faktor analize. Takav pristup omogućuje odvajanje objektivne vrednosti od subjektivne, dok tehnika u celini pruža formalizaciju makroekonomskih problema u makroekonomiji.

Ključne reči: kognitivno modeliranje, ujedinjene strategije, donošenje odluka, strukturni problemi, makroekonomske analize, metode generalizacije, multikriterijumi
\end{abstract}

